\title{
THE FOX THAT STOLE THE APEX OF PALLISER'S TRIANGLE: ACORRECTION
}

JAMES K. FINLEY, 10232 Summerset Place, Sidney, B.C. V8L 4X2

E-mail: <jameskfinley@islandnet.com>

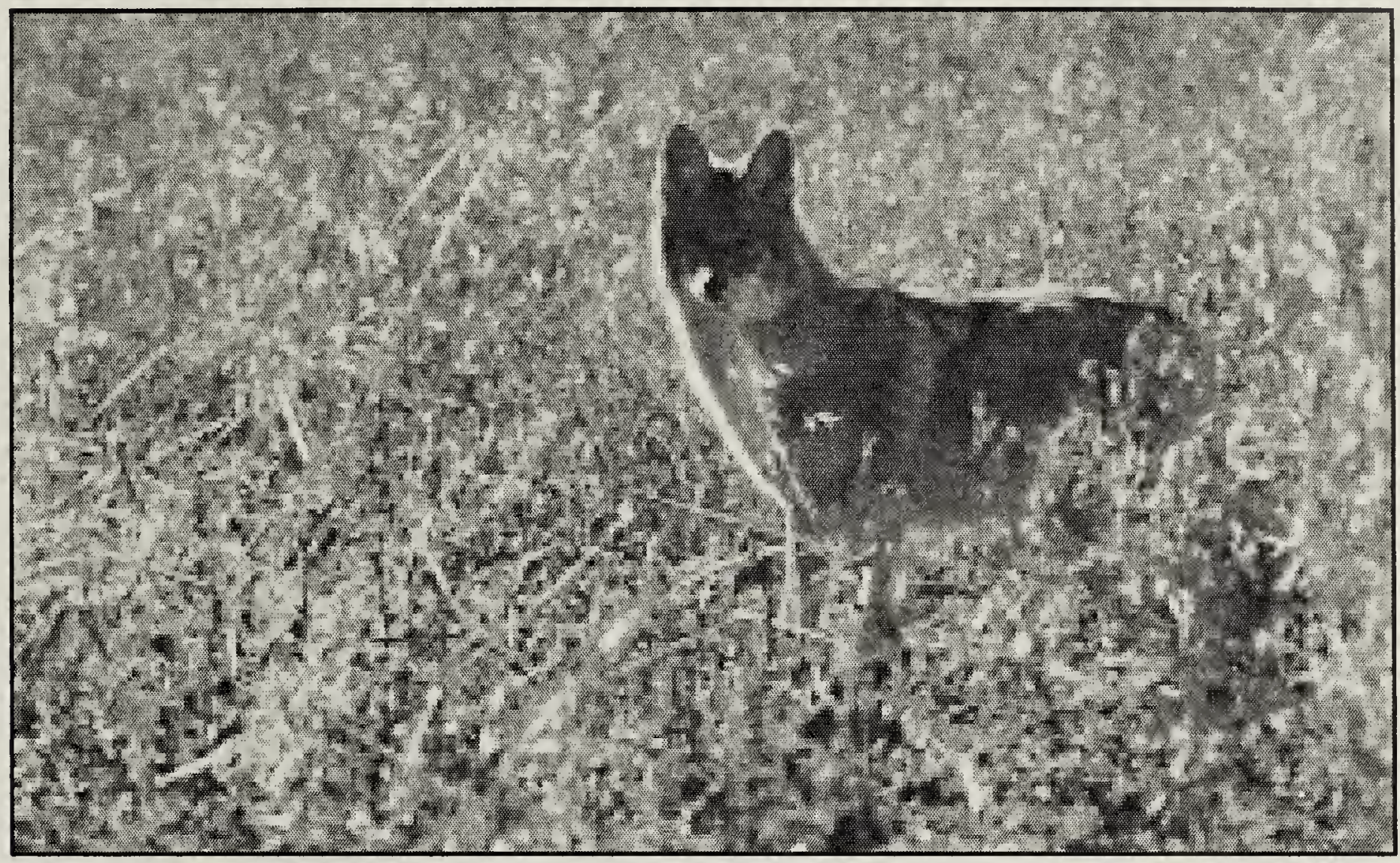

Satiated coyote near the Luseland sewage lagoons in late October 2002. Coyotes have regained control of much their former domain, and they may retain it, depending on our changing attitudes and policies.

J. K. Finley

My father, Bob Finley, and Sig Jordheim were both born in 1921 on their father's homesteads, just 45 miles apart, between the North and South Saskatchewan rivers ... that is, at the heart of Palliser's Triangle. As the first generation of sod-busting pioneers, they experienced much in common through the first century, raising their families on grain farms, both attuned to the land, sharing a keen interest in wildlife. This common heritage set the stage for a remarkable coincidence: they both killed the first Red Fox they ever laid eyes on. In doing so they established two significant milestones in the annals of prairie natural history. Both events were recorded in Blue Jay, the first as a note by Mr. Jordheim, in 1995, the second as my response to that note. ${ }^{1,2}$

That first fox made a big impression on Mr. Jordheim, and three decades later he recalled the event as if it was only yesterday. "My first contact with a wild Red Fox came on 17th November 1966 when it ran onto the road in front of my truck, two miles north of my present farm [ near Kyle on the north side of the South Saskatchewan River]. The snow was perhaps 10" deep and 
the fox chose to stay on the hard track. I slowed down to give it a chance to get off, but it would not, so deciding this was a good chance to destroy it, as I raised poultry, I stepped on the gas and drove over it, stopping immediately and picking it up. It was killed instantly and I found it was a female, weighing 10 pounds and measuring 44" in length." $\mathrm{He}$ wondered whether the fox had escaped from a fur farm, and noted that they became plentiful in the 1970s and 1980 s, following a great decline in jackrabbit populations.

His recollection prompted my own of the first fox that my father or I had ever seen near Luseland, about 110 miles NW of Kyle (i.e. beneath the apex of the Triangle). I recalled that it happened in early winter a year or two earlier than Jordheim's record (i.e. 1964 or 1965), and suggested that the subsequent invasion was due, indirectly, to the snowmobile revolution and removal of the apex predator, the Great Plains Coyote (Canis latrans latrans), from the prairie ecosystem. ${ }^{2}$ As it turns out, my memory of the date was faulty, throwing a wrench into my thesis, which I'm obliged to fix.

The truth was handed to me by my mother, in a bulging manila envelope, not long after my son's graduation from Grade 4. It remained sealed until one autumn afternoon when the time seemed ripe for its revealing. Therein, amongst documents from my early education, I found a scribbler, not much larger than the Blue Jay. It had a tactile, electric-blue cover that elicited vaguely unpleasant sensations. Skimming the first few pages of grammatical exercises, pencilled in long-hand, I encountered my first lesson in correspondence, dated November 23rd, 1960. It was an invitation to a friend to come to my place for a party. With a jolt, I found myself transported back to a living nightmare-the dungeon of Grade 4 and the dragon of Mrs. Klass. It was the grim year of the 'Uncle Funny Bunny' reader, interminable times tables, and staying after school to write lines.

Turning a few more pages, I came across my next correspondence lesson, the subject of which caused my jaw to drop: "Will you come to my place. We have a red fox." The ghost of my past practically leapt off the page and handed me the answer to an outstanding question that I thought would never be asked, let alone answered: When, exactly, did that first Red Fox trespass beneath the apex of Palliser's Triangle? The correspondence was dated December 5, 1960.

My exercise received three $X$ 's for punctuation and content, so, on the following page, l'd re-written it, clarifying that "We shot a red fox." and that, "We went after the fox. We raced through trees and bob [sic] wire." For that exciting news, I received a curt red check mark. Maybe she thought I was a liar since nobody had ever seen a fox on the prairies, let alone killed one. But I was a liar anyway, I recalled, for that fox was in the middle of a snowcovered stubble field, with not a tree or 'bob wire' fence in sight. Like a bad case of deja vu, I found myself back in that grim class room, helplessly struggling with words to describe the most exciting moment of my life. Undoubtedly, my mind was still on fire from the excitement of the chase, and I could barely contain myself until the bell rang, and l'd show my friends the prize.

I was still smiling at my good fortune when my son arrived home from school ( by which time he was in Grade 5). Triumphantly, I showed him the blue scribbler and attempted quickly to 
encapsulate all that it meant, employing a bit of hyperbole: It's proof of the first fox to have trespassed into the coyote's kingdom. It's not like it used to be, I opined, as fathers are wont to do. But his attention was drawn to the bold X's. On those, the teachers were much stricter in the old days, and Mrs. Klass was the strictest teacher in the school, if not the whole province. Anyway, I said, pointing to the embellished version, I got it right the second time.

To be more precise, that fox was likely killed on the morning of Sunday, December 4th, because that's when my father would have been evading church, cruising the country-side, hunting jackrabbits and coyotes with his boys. It was six miles due north of town at $52^{\circ} 11^{\prime} \mathrm{N}, 109^{\circ} 22^{\prime} 30^{\prime \prime} \mathrm{W}$. Like a misplaced specimen tag, the entry in my blue scribbler gives authenticity and context to the record. First, it represents the earliest record of the invasion in the region immediately beneath the apex of the Triangle. Second, it occurred six years earlier than Sig Jordheim's record, further south.

As soon as I was able to reconcile my memory (this was Before Beatles!), I attempted to recall when I saw the next fox. I remembered the occasion well, partly because of a guilty conscience: I'd taken my father's riflethe one he'd used to slay the first foxwithout permission. Spare the details, but in confessing my misdeed, we deduced that it happened in the late winter of 1963. Had they been present before then, I'm certain that I or a member of my hunter-naturalist family would have known.

They became established within a couple years. I recall finding the first den with kits in a small pasture, a mile southwest of town, on the same knoll- if not actually in the same burrow-that had once been occupied by Burrowing Owls. In about 1966, I showed Stuart Houston a Great Horned Owl nest in an aspen grove in this same pasture, by which time the Burrowing Owl nest site had been taken over by foxes. Thus, foxes were already established near the apex, before Mr. Jordheim saw his first one, over a hundred miles further southeast. By the late 1960s, they were common, and by the early 1970s, they had become abundant, causing ecological havoc. ${ }^{2}$

Contrary to my earlier thesis, the 'first' fox appeared before the snowmobile revolution began in earnest. In fact, it appeared only a year after the 'Father of the Snowmobile', Monsieur Bombardier, began mass production of the Ski-Doo, a machine that was to revolutionize winter life and bring about a drastic decline of the coyote.

In an earlier paper in Blue Jay, Nora Stewart of Craven (just north of Regina) noted that there had been a "tremendous increase in foxes along with the decrease in coyotes in Saskatchewan since the late 1950s."3 She suggested that the rapid decline of the coyote was due to public poisoning programs, and wondered what the 'balancing effect' of the coyote was on the fox population. It was a prescient question that, remarkably, has been ignored until only recently.

For an earlier local perspective than my own, I contacted my father's cousin, Bennett Finley. He replied: "Certainly your recollections re: red foxes agree with mine. There were NONE when I was growing up and I used to hunt coyotes with your Dad at that time. Nor were there any deer, antelope or moose in the greater Luseland area. (40s and 50s) I think that the great decline in coyotes over the larger area 
was due to poisoning which was very widespread and often talked about by farmers and ranchers. Not so prevalent around Luseland as in other areas.... None of us liked this poisoning--not from any great ethical reasoning but because we wanted coyotes to hunt."

Thus, by 1960 , before snowmobiles came into widespread use, coyotes had already been reduced in number, but the main invasion of foxes occurred in the last part of the 1960s, after the slaughter of coyotes by snowmobilers had occurred. (The slaughter was exacerbated by the heavier-thannormal snowfall during this period, along with a buoyant economy that encouraged winter 'sports,' before ethical considerations arose and laws became entrenched.) In this respect, Sig Jordheim's record of November 17th, 1966 marks a significant milepost in the progress of the invasion at the heart of the Triangle.

\section{Post Script}

On February 28th, 2005, while driving east along a grid road, only 3 miles from where the first fox was killed, my brother and I encountered a Red Fox (at 52 $10^{\prime} 40^{\prime \prime} \mathrm{N}, 109^{\circ} 26^{\prime} 40^{\prime \prime}$ $W$ ). It was a balmy sunny day and the fox was sleeping in a snow-covered stubble field, near the road. As in the case of the first fox, there wasn't a tree or 'bob wire' fence in sight. From a biogeographic perspective, 45 years apart, they had been caught in the open on the south bank of a broad glacial valley (Grassy Lake), once renowned for its rich dark soils and lush growth of 'prairie wool' or fescue grassland. It struck me then that their close proximity was not entirely coincidentalthey were situated in a sort of noman's land, where virtually all native prairie had been plowed under, and where there were no 'prairie wolves' to keep them out. Nature abhors even the smallest vacuum; foxes will continue to hang on where they can.

\section{Acknowledgements}

In memory of Alice Klass who, from 1949 to 1970 , taught us 'Luseluddites' how to read, write, and do arithmetic. As ruthless as Mother Nature, her nononsense, even-handed, spare-thepraise approach to life better prepared us for the rigours of life beneath the apex. This essay is dedicated to my father, the nimrod who collected the first fox, and to my mother, the archivist who kept the evidence.

1. JORDHEIM, S. 1995. Foxes in southcentral Saskatchewan. Blue Jay 53 : 232-233.

2. FINLEY, J.K. 1996. The red fox invasion and other changes in wildlife populations in west-central Saskatchewan since the 1960s. Blue Jay 54 : 206-210.

3. STEWART, N.M. 1969. Coyote management in Saskatchewan: is poison the answer? Blue Jay 30: 138 $-145$.

"The Double-crested Cormorant is a diver, using its webbed feed to propel it underwater on its hunt for fish. To help it sink, a cormorant's feather are not waterproof, so it must spread its wings to dry when it has finished fishing." 